\title{
Microbial IC95 Fold Change from Ref
}

National Cancer Institute

\section{Source}

National Cancer Institute. Microbial IC95 Fold Change from Ref. NCI Thesaurus. Code C139123.

A fold change based on the concentration of a specific drug expected to produce 95 percent inhibition on the enzymatic activity of a microbial organism; it is a ratio calculated by the IC95 Subject Result divided by the IC95 Reference Control Result. 